\title{
Post Herpetic C8 Myotomal Paresis Post Herpetik C8 Myotomal Parezi
}

\author{
Tuna Özmen 1 , Ömer Lütfi Gündoğdu11, Okan Doğu² \\ ${ }^{1}$ Recep Tayyip Erdoğan University Research Hospital, Clinic of Neurology, Rize, Turkey \\ ${ }^{2}$ Mersin University Faculty of Medicine, Department of Neurology, Mersin, Turkey
}

\section{Summary}

Herpes zoster is a neurocutaneus infection of latent varicella-zoster virus. It occurs by the reactivation of virus in sensory ganglia and causes pain and rash in related dermatome. Although it is a disease of sensory ganglia, myotomal paresis can develop. Motor involvement generally affects cranial nerves but motor palsies of spinal roots are uncommon. We present a patient with postherpetic spinal segmental paralysis, which developed after a rash on the right upper extremity had resolved.

Keywords: Neuropathology, neuroinfection, neuromuscular disease, pain

Öz

Herpes zoster, latent varicella zoster virüsünün nörokutanöz bir enfeksiyonudur. Virüsün duysal ganglionda reaktivasyonu sonucu ortaya çıkar ve ilgili dermatomda ağr1 ve döküntüye sebep olur. Her ne kadar duysal ganglionun hastalı̆̆ olsa da, myotomal pareziler gelişebilir. Motor tutulum genellikle kranyal sinirleri içerir ve spinal köklerin motor parezileri yaygın değildir. Burada, să̆ üst ekstremitesinde döküntü sonrası postherpetik spinal segmental paralizi gelişen bir hasta sunulmuştur.

Anahtar kelimeler: Nöropatoloji, nöroenfeksiyon, nöromüsküler hastalık, ağr1

\section{Introduction}

Herpes zoster is a common viral infection and occurs in the sensory ganglia due to VZV. It usually manifests with radicular pain and vesicular cutaneus eruptions along a single dermatome (1). It is a disease of sensory ganglia but motor involvement is not rare and transient paresis can develop. It usually affects cranial nerves but motor paresis of spinal roots is uncommon. The involvement of upper extremities by herpes zoster infection commonly occurs in the C5-7 myotomal distribution $(2,3)$. Paresis of C8 myotome is very rare and can be confused with cubital tunnel syndrome (4). Here, we present a patient aged 46 years with postherpetic spinal segmental paralysis in the C8 myotome. Informed consent was obtained from the patient for the publication.

\section{Case Report}

A man aged 46 years presented with pain in the right shoulder and upper arm. Skin lesions occurred in the same localization after 10 days. During dermatologic examination, multiple vesicular lesions were seen over the right shoulder, arm, and forearm. The patient's general physical-, systemic-, and neurologic examinations were normal. Biochemical and infectious markers revealed no abnormalities. He was diagnosed as having herpes zoster infection and treated with acyclovir $1000 \mathrm{mg} /$ day, followed by gabapentin titration for neuropathic pain control. Four weeks after the skin lesions, he was referred with right hand weakness, decreased sensation in the third through fifth fingers, and right arm pain in the C8 dermatome. A neurologic examination detected 4/5 strength in finger flexors and abductors. The thenar muscles of 
the right hand were hypotonic and paresthesic. Our findings suggested lower motor neuron paralysis. The radiologic imaging for differential diagnosis with spinal pathologies was normal. Two weeks after the onset of pain, an electrodiagnostic investigation was ordered for his right arm. Median and radial compound motor action potentials were normal, but ulnar nerve action potentials were abnormal. Both sensorial and motor action potentials of the ulnar nerve could not be obtained. There was no denervation potential in the needle electromyogram (EMG) examination. He was given $1800 \mathrm{mg} /$ day gabapentin therapy for 5 months after which the nerve conduction studies were repeated. The later neurologic examination showed just paresthesies in the right $\mathrm{C} 7$ and C8 dermatomal areas and there was no motor deficiency. Nerve conduction studies of the right ulnar nerve demonstrated decreased distal ulnar compound motor action potential amplitude and proximal action potentials could not be obtained. Needle EMG examination showed partial chronic denervation of the right C8-innervated muscles, including the abductor pollicis brevis, the third and fourth dorsal interosseous, and abductor digiti minimi. Eleven months after the onset of pain, the patient continued to experience hand numbness and weakness but there was no pain and gabapentine therapy was gradually stopped.

\section{Discussion}

Herpes zoster infection is caused by reactivation of latent endogenous varicella-zoster virus in sensory ganglia (1). The primary infection has a viral prodrome and manifests with a vesicular rash. The virus then settles in the dorsal root ganglion and can causes a herpes zoster infection years later. Age, immunsupressive diseases or drugs, and trauma are some of the responsible factors of reactivation $(4,5,6)$. The initial symptoms of infection are usually pruritis, paresthesia, or allodynia along a unilateral dermatome in the prodromal period. After several days, a maculopapular and vesicular rash is seen in the same dermatomal area. The virus usually affects sensory ganglia and motor neuropathy is not common. Only $5 \%$ of cases have myotomal involvement and motor paralysis is mostly seen in cranial nerves (7). Involvement of limbs through spinal nerve involvement is uncommon. In the literature, Mondelli, Haanpaa and Akiyama $(8,9,10)$ reported similar cases in series and there are a few reports from India $(11,12)$. Myotomal paresis usually develops in the first few weeks after the onset of rash. It commonly affects cranial nerves and proximal upper extremity. If an upper extremity is affected, involvement of $\mathrm{C} 5-7$ distribution has a higher ratio; $\mathrm{C} 8$ myotome is rarely involved $(2,3)$. Isolated $\mathrm{C} 8$ paresis can be confused with cubital tunnel syndrome and EMG studies are required for the diagnosis. In cubital tunnel syndrome, conduction block or focal conduction that slows at the elbow can be expected. Conduction velocity can also be found decreased at the elbow, but normal in the forearm $(4,13)$. In our case, serial EMG and nerve conduction studies including inching were performed and there was no any evidence that suggested ulnar nerve compression. Motor paralysis after herpes zoster infection has a relatively good prognosis (14). The recovery ratio and time can vary from patient to patient and early application of antiviral therapy can reduce motor involvement $(1,8,9)$. Fifty-five percent of patients recover completely and $30 \%$ gain partial improvement over months to years (4).

Informed Consent: Consent form was filled out by all participants, Concept: Tuna Özmen, Ömer Lütfi Gündoğdu, Okan Doğu, Design: Tuna Özmen, Data Collection or Processing: Tuna Özmen, Ömer Lütfi Gündoğdu, Okan Doğu, Analysis or Interpretation: Tuna Özmen, Literature Search: Tuna Özmen, Writing: Tuna Özmen, Peer-review: Externally peer-reviewed, Conflict of Interest: No conflict of interest was declared by the authors, Financial Disclosure: The authors declared that this study has received no financial support.

\section{References}

1. Strauss SE, Kenneth ES, Oxman MN. Varicella and Herpes zoster. In: Freedberg M, Eisar AZ, Wolff K, Austen KF, Goldsmith LA, Katz SI (eds). Fitzpatrick's Dermatology in General Medicine. 6th ed. New York: Mc Graw Hill, 2003;2070-2085.

2. Kawajari S, Tani M, Noda K, Fujishima K, Hattori N, Okuma Y. Segmental zoster paresis of limbs, report of three cases and review of the literature. Neurologist 2007;13:313-317.

3. Yoleri O, Olmez N, Oztura I, Sengül I, Günaydin R, Memiş A. Segmental zoster paresis of the upper extremity: a case report. Arch Phys Med Rehabil 2005;86:1492-1494.

4. Kreps CE, Rynders SD, Chhabra AB, Jenkins JG. C8 myotome herpes zoster paresis. Am J Orthop (Belle Mead NJ) 2012;41:220-222.

5. Cohen JI, Brunell PA, Straus SE, Krause PR. Recent advances in varicalla-zoster virus infection. Ann of Intern Med 1999;130:922-932.

6. Donahue JG, Choo PW, Manson JE, Platt R. The incidence of herpes zoster. Arch Intern Med 1995;155:1605-1609.

7. Sterling JC, Kurtz JB. Varicella(Chickenpox) and zoster(shingles). In: Champion RH, Burton JL, Burns DA, Breathnach SM (eds). Rook, Wilkinson,Ebling Textbook of Dermatology. 6th ed. London: Blackwell Sciences, 1998:10151022 .

8. Mondelli M, Romano C, Passero S, Porta PD, Rossi A. Effects of acyclovir on sensory axonal neuropathy, segmental axonal neuropathy, segmental motor paresis and postherpetic neuralgia in herpes zoster patients. Eur Neurol 1996;36:288-292.

9. Haanpaa M, Hakkinen V, Nurmikko T. Motor involvement in acute herpes zoster. Muscle Nerve 1997;20:1433-1438.

10. Akiyama N. Herpes zoster infection complicated by motor paralysis. J Dermatol 2000;27:252-257.

11. Nigam P, Tandon VK, Kumar R. Herpes zoster: a clinical study. IJDVL 1972;38:152-155.

12. Chaudhary SD, Dashore A, Pahwa US. Clinico epidemiological profile of herpes zoster in North India. IJDVL 1987;53:312-316.

13. Preston DC, Shapiro BE. Electromyography and Neuromuscular Disorders: Clinical-Electrophysiologic Correlations. 2nd ed. Philadelphia, PA: Elsevier, 2005.

14. Bradley GB. Myelopathies affecting anterior horn cells, In : Dyck PJ, Thomas PK, Lambert HE (eds). Peripheral Neuropathy. 2nd ed. Philadelphia: WB Saunders, 1984:1351-1367. 